\title{
Impact of Commercial Motorcycle Operation on Urban Mobility in Ogun State, Nigeria.
}

\author{
Oluwa seyi J oseph AFOLABI ${ }^{*}$ Kola wole Ta ofeek GBADAMOSI² \\ ${ }^{1}$ Bells University of Technology/Depa rtment of Mana gement Technology, Ota, Nigeria \\ 2 Federal University of Technology/Department of Transport Mana gement Technology, Akure, \\ Nigeria
}

\begin{abstract}
The significant of public transport of cities in many developing countries lies in the fundamental fact that mobility and accessibility are essential for economic growth and of necessity to provide efficient and effective movement for goods and senvices. The collapse of public intra-city transport system paved way for the rise of motorcycles as means of public transportation in Nigenia. This paper discusses the impact of commercial motorcycle operation as a means of urban transportation. Of the 200 questionnaires administered, 191 questionnaires were received for analysis using the Statistical Package for Social Sciences (SPSS). Secondary data was also sourced to sene as complement to the primary data, thus allowing for a robust research. Descriptive statistical tools such as percentages were adopted to present the socio - economic characteristics in the area. Findings showed that the majority of the users are adult between the aged 31 and 40 years. Most of them (53.8\%) are mamied and are fairty educated. Furthermore, it was recommended that the Nigerian govemment should provide employment opportunities for our teeming youth as this will go a long way in the reduction of number of youth who as a result of unemployment took to motorc ycle riding business.
\end{abstract}

Key words - Transportation, Traffic, Motorc ycle, Ogun State

\section{INTRODUCTION}

Transport is a critical sector of the Nigerian economy, whose catalytic effect, particularly on socio-economic development, cannot be overemphasized [1]. The huge investment by the different tiers of govemment and private sector investors in transport infrastructure provision and the delivery of transport services in Nigeria underscores the pivotal role of transport in the overall development of the country. Besides, there is hardly any sector of the economy - whether the ind ustrial, employment, residential, rec rea tional and to urism, or a gric ultural sectors - that is not linked to the tra nsp ort sector. In Nigeria, road transport is the dominant mode of movement for both freight and passenger traffic. The impact of the railway has been dwindling and it eventually collapses about a decade ago. Air transport is unavailable to the urban poor while the potentials of water for inland transportation have not been fully exploited. The mono transport mode nature of urban mobility in the country has been responsible for the collapse of public transport and the concomitant suffering of commuter in urban centres [4]. In short, the effic iency and effectiveness with which the mobility and accessibility of passengers and goods are achieved would determine the level of performance of the transport sector among other things. Indeed, the transportation challenges often faced in many cities of the world attracted research efforts by the academic, institutional agencies and world socio-economic organizations to long lasting solution to this regards [15].

The significant of public transport of cities in many developing countries lies in the fundamental fact that mobility and accessibility are essential for economic growth and of necessity to provide efficient and effective movement for goods and services. The failure of the public transportation system however and ind eed overa ll transportation system in the cities has led to further ma rgina lization of the greater majority of the people in these cities and consequently; economic deprivation [14]. Transport creates time and place utilities by changing the geographical position of goods and people. This role becomes more signific ant if one realized that, spatial pattem of demand does not 
correspond with spatial availability of supply. Therefore, transport is needed as an intervening opportunity to overcome the spatial differences and regional inequalities through technological advancement, man has been able to develop various form of transport that enable him to travel in any medium of the environment through water, land and air. In addition, the general growth in population and increase in rural-urban movement led to congestions in urban cities and rapid growth of transportation system. This also resulted in high demand on transport system. At this, the conventional urban transport which consists of buses and taxis could no longer effectively fill the transportation need of our urban cities.

Urban transportation in Nigeria has been largely by road. Indeed, of the trips made by vehic les, seventy percent are done through the private sector dominated public transport [12]. Currently, of this figure, motorcycles as means of commercial transportation have the highest percentage in intra-city transport in Nigeria. A decline in organized public transport systems has led to rapid growth in non-conventional means of public transport, initially provided by minibuses and shared taxi/vans, and more recently by commercial motorcycles. The use of motorcycles for urban transportation is not a new phenomenon in Nigeria. Over the past decades there has been a signific ant growth in the use of motorcycle as a means of transportation. The important operation of motorcycle in savaging urban mobility problems in Nigeria has introduced a new dimension to traffic accidents and safety in the country [2].

The govemment's inability to provide conventional mode of transport has necessitated the use of motorcycles (two-wheel automobiles) and tric ycles (three- wheel a utomobiles) to move people, goods and servic es from one point to a nother under conditions considered to be unsafe and accident-prone. The inability to provide adequate motor vehicles for urban transportation has caused the influx of motorcycles for urban public transport into cities in Nigeria, thus the increase in the use of motorcycle for urban mobility came about in order to fill the gap in the demand and supply of public transport in most urban centres in the country [9]. Motorcycles are now one of the primary modes of transportation in Nigeria, and comprise a cheap and adaptable transportation system, the most popular informal one in the country by far. Even in remote villages, they a mive at regular intervals. It has become a means of transportation regularly used by the young and the old, and men and women.

Furthemore, the introduction of motorcycle popularly called Motorcycle as an altemative mode of transport was prompted by the high cost and unenviable transport provision which impacted negatively on economic activities and mobility of the urban populace.

It can only be assumed that this mode therefore evolved as public commercial transport in response to need but there could be several other underlining factors. The understanding of these factors is crucial in planning for this mode of transport which hitherto has no role to play on any urban routes as intra-c ity public transport [6].

\section{STATEMENTOF RESEARCH PROBLEM}

The emergence of motorcycles in Nigeria has resulted into lots of problems. The adoption of motorc ycle for urban movements on most Nigerian cities can said to be a major contributing factor to changes in the trend of road traffic accidents in Nigeria. In the last two decades, mobility and accessibility problems appear to have been the main challenges facing Nigeria and her cities in the country's desire for development. The govemment's inability to provide conventional mode of transport has necessitated use of motorcycles and tricycles to move people, goods and services from one point to another under conditions considered to be unsafe and accident-prone [11].

The growth pattem in the state have also complic ated transport demand situation in the state. Public transportation services within the state have also been insufficient. Thus, inadequate and ineffic ient transport situation a re issues of major concem in Ogun State.

The setting up of the Federal Road Safety Corps seems to have focused mainly on motor vehicles safety ignoring completely the modus operadi of commercial motorc yc le passenger operators especially as it affects safety and the environment. 
Another worisome perspective to this problem is the use of motorcycles by men of the underworld to rob people of their valuables, dupe unsuspecting passengers as well as kid nappings, rituals etc.

Currently, It is a disturbing dimension as any minor misunderstanding between a motor vehicle driver and a commercial motorcycle passenger operator could lead to the former being mobbed or having his vehicle razed or vandalized. The attempt to alleviate urban mobility problem should take into consideration the need to reduce the poverty level of most urban dwellers. This may involve a tumaround of the nation's economy. The economic reengineering process must vigorously pursue localized sectoral and microeconomic polic ies that will favour labour intensive urban activities.

The situation with respect to the dangerous trend in the operation of motorcycles in urban centrescalls for a radic al a p proach towards finding effective solutions to the problem of loss of property and human life associated with motorcycle. The current situation calls for a better integration of the activities of the motorc ycle operators as part of the large urban transport system. It is important to make the operation of the motorcycles more refined considering the poverty level of urban residents coupled with the restricting of their choice as result of own availability of reliable public transport service.

\section{UTERATURE REVIEW}

Transport is a lso significant to the society in promoting national unity and social integration, generating sense of transport is further evident in the fact that the world's biggest cities are found in foci of transport routes - rail, water, road and air [3].

The demand for transport services in Nigeria cities has grown over the years and the quality of a vailable transport infrastructure and servic es have deterio rated drastic ally [8].

Mobility refers to the speed of travel and the manner in which travel is undertaken. It is a reflection of people's individual persona lities and their status. Different modes of transport offer different levels of mobility and accessibility under different circumstances. By and large, people seek to increase their mobility to improve accessibility which is the ease with which desired social and economic activities can be undertaken from a specific point in space [10].

The crisis that engulfed the process of urban mobility in Nigeria in the early 80 's arising from the collapse of govemment organized urban mass transit subsequently made commuting in most urban centres a diffic ult task. This made the introduction of altemative approach of easing the movement of urban commuters imperative. The dimension and pattem of road traffic accident has been adversely affected with the emergence of motorcycle as an altemative in the process of a meliorating the diffic ulties encountered by urban commuters [1].

The closeness of the state to Lagos has caused urban mobility problems which have necessitated the use of motorcycle as a means of road transport, this as a result of congestion.

In many Nigerian cities, transport situation has reached a crisis point; the consequence of several years of neglect by succeeding administration. Hence, there is nothing novel in stating that transportation in Nigeria is grossly ina dequate [13]. In the last decade, most people in urban areas have depended heavily on motorcycle as a means of transport. The few of the populace that have access to private motorized means; either for unavailability of spare parts or because of its prohibitive price of moving a round, find it extremely diffic ult to ma inta in them. In other words, poor quality, unaffordable, unsafe and grossly uncomfortable means of mobility in Nigeria cities pose great threat to people.

There are various works on para-transit modes of transport services. Para-transport or intermediate public transport mode is the form usually applied to small passenger transport vehic les operating informally on a fee paying basis [5]. This is the category into which commercial motorc ycle belongs. [7] goes further to state that Para-transit modes are described as passenger vehicles that provide services that fall in-between conventional public transport services (which are usually better organized and run according to schedule) and private transport service. 


\section{Log istics \& Susta ina ble Tra nsp ort Vol. 8, No. 1, May 2017, 62-71 doi: 10.1515/jlst-2017-0006}

Various studies have revealed that public transport especially in developing countries a re ma inly road based and comprised buses which are often complemented by a variety of intermediate, informal or Pa ra-transit services.

Since political independence in the 1960s, development of the transport infrastructure has concentrated on very systematic expansion and improvement of the road system.

The Nigeria situation is precarious as the infrastructure is completely lacking leaving the motorcyclists to struggle for a vailable road space with motor vehicles thereby endangening man, machine and the environment.

There was a study by Olagunju [11]. His findings indicated that motorcycles as a means of movement enjoy high level of patronage among young and adults, low and middle income eamers as well as people with low educational qualific ation. He also found out that the business of motorc ycle operation is very profitable and that most of the operators do not have altemative means of livelihood. He, however, found out that the mode is very unsafe and faced with numerous environmental and social problems. See "fig.1," below.

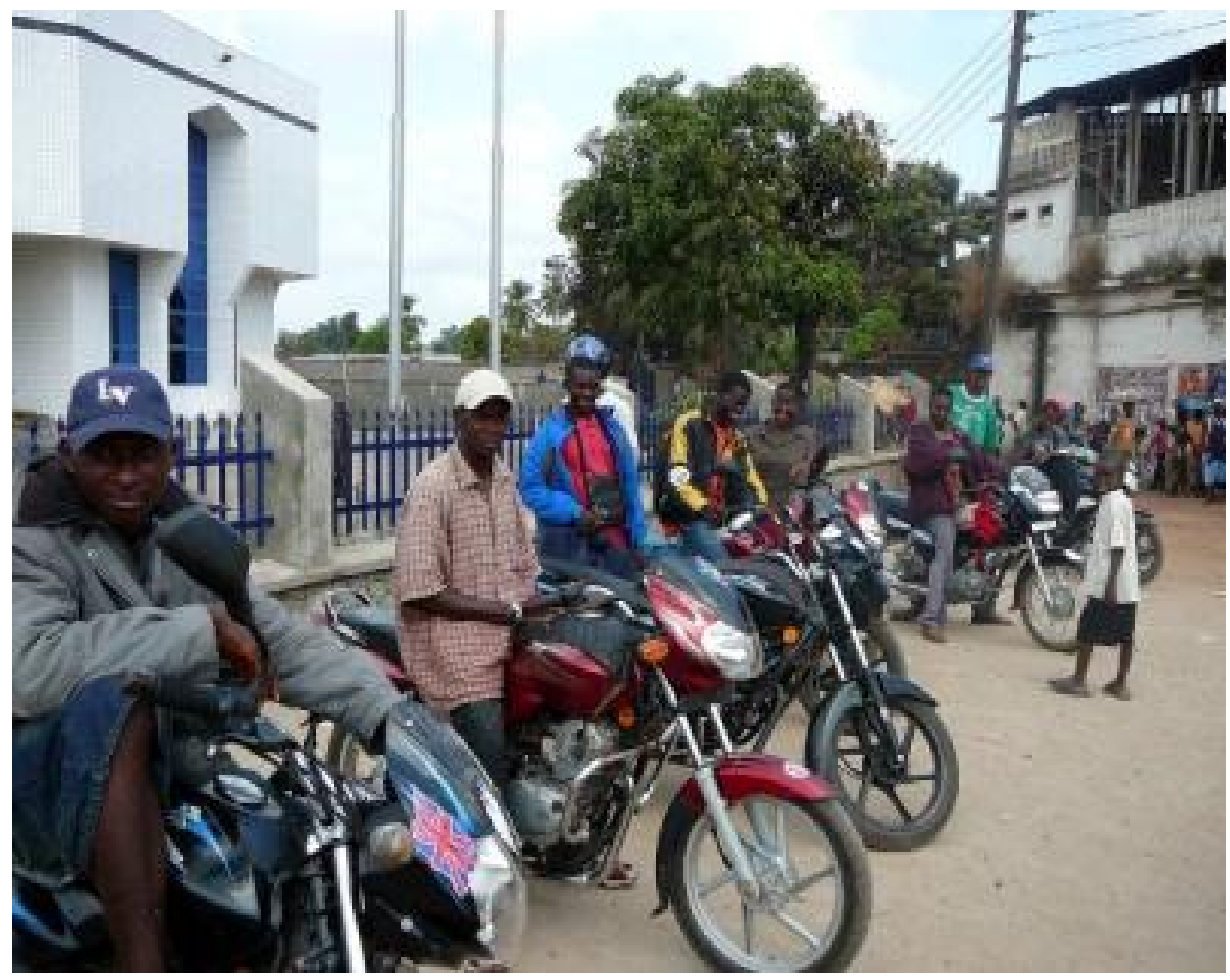

Figure1: Okada Riders Awaiting Passengers 


\section{THE METHODS}

A total of two hundred questionnaires was considered a dequate by the a uthor for this research, 191 questionnaires were received for analysis using the Statistical Package for Social Sciences (SPSS), and the questionnaire was structured to elic it information from the respondents on their socio-economic characteristics; their perception on commercial motorcycle operation on urban transportation using Ifo Local Govemment Area as a case study. Data used in this study emanated from both primary and secondary sources. The primary information for this research was sourced through the use of structured questionnaire, personal observation and interviews on commercial motorcycle users in the study area. Secondary data emanated from published and unpublished sources such as govemment records, intemet, joumals, books etc. The findings were presented in descriptive form using frequencies, percentages, tables, mean and standard deviations. The sequence of presentations was presented with the bio-data of the respondents and the research question.

\section{RESULTAND DISC USSION}

The specific socio-economic characteristics of respondents considered are gender, education, age and factors influencing their patronage of motorcycle. The elicited responses are presented in the tables below.

After collating the data generated from the survey on users of motorcycle, it was discovered that $63.8 \%$ of the users of motorc yc le in Ifo LGA are males while the remaining $37.2 \%$ are females.

Table 1. Gender of the User of Motorc ycle operators

\begin{tabular}{|ll|l|l|}
\hline & & Frequency & Percent \\
\hline Valid & Male & 120 & 62.8 \\
& Female & 71 & 37.2 \\
& Total & 191 & 100.0 \\
\hline
\end{tabular}

Source: Field work, 2016

In terms of the age of the user of motorcycle in the study area, it was observed that $5 \%$ of them are of ages less than 20 years, $20.4 \%$ are of the a ges between $20-29$ years, $37.1 \%$ are of the ages between 30 - 39 years, the age range of $23.5 \%$ of them is 40 - 49 years, $9.0 \%$ said their ages is between 50 - 60 years while the remaining $5.0 \%$ sa id they are more than $60 y e a r s$.

Table 2:.Age of the respondent

\begin{tabular}{|ll|l|l|}
\hline & Frequency & Percent \\
\hline Valid & Below 20 years & 10 & 5.0 \\
& 20 - 29 years & 39 & 20.4 \\
30 - 39 years & 71 & 37.1 \\
40 - 49 years & 45 & 23.5 \\
50 - 60 years & 17 & 9.0 \\
Above 60 years & 9 & 5.0 \\
Total & 191 & 100.0 \\
\hline
\end{tabular}

Source: Field work, 2016 


\section{Log istics \& Susta ina ble Tra nsp ort Vol. 8, No. 1, May 2017, 62-71 doi: 10.1515/jlst-2017-0006}

The level of education of the users was taken into consideration, it revealed that $4.9 \%$ of those that use the motorcycle as a mode of transportation have primary school level of education, $37.1 \%$ of them said they had secondary school level of education, and $56.0 \%$ sa id they have tertiary level of education while the rema ining $2.0 \%$ have other forms of educ ation.

Table 3. Educational qua lific ation of respondents

\begin{tabular}{|ll|l|l|}
\hline & & Frequency & Percent \\
\hline Valid & Primary education & 9 & 4.9 \\
& Secondary education & 71 & 37.1 \\
& Tertiary education & 107 & 56.0 \\
& Others & 4 & 2.0 \\
& Total & 191 & 100.0 \\
\hline
\end{tabular}

Sourc e: Field work, 2016

Out of the 191 users of motorcycle used for the study, it was observed that $53.8 \%$ of them are maried, $1.9 \%$ are divorced, and $3.6 \%$ are widowed while the remaining $40.7 \%$ are single. This distribution appears to have a fair representation of the people in the various category of marital status, indic ating that marital sta tus is not a deterrent to the use of motorc ycle operators in the study area.

Table 4. Marital status of respondent

\begin{tabular}{|ll|l|l|}
\hline & & Frequency & Percent \\
\hline Valid & Mamied & 103 & 53.8 \\
& Divorced & 3 & 1.9 \\
& Widowed & 7 & 3.6 \\
Single & 78 & 40.7 \\
& Total & 191 & 100.0 \\
\hline
\end{tabular}

Source: Field work, 2016

The questionnaire used to gather information also measured the occupation of the users of motorcycle in the study area, it was disc overed that $27.2 \%$ of the users are self employed, $20.9 \%$ said they are civil servants, $38.2 \%$ of them work in private orga nizations, $11.0 \%$ are students while the remaining $2.7 \%$ have other forms of occupation.

Table 5. Occupation of respondent

\begin{tabular}{|ll|l|l|}
\hline & & Frequency & Percent \\
\hline Valid & Self employed & 52 & 27.2 \\
& Civil servant & 40 & 20.9 \\
Private employment & 73 & 38.2 \\
Student & 21 & 11.0 \\
Others & 5 & 2.7 \\
Total & 191 & 100.0 \\
\hline
\end{tabular}

Sourc e: Field work, 2016 
From the table below, it shows that $83.2 \%$ of the respondents used for the study make use of commercial motorcycle, $14.2 \%$ of them said they do not patronize them while the remaining $2.6 \%$ did not answer the question.

Table 6. Respondents patronage of commercial motorcycle operators

\begin{tabular}{|ll|l|l|}
\hline & & Frequency & Percent \\
\hline Valid & No response & 5 & 2.6 \\
& Yes & 159 & 83.2 \\
& No & 27 & 14.2 \\
& Total & 191 & 100.0 \\
\hline
\end{tabular}

Sourc e: Field work, 2016

The reason for patronizing the motorcycle operators is shown in the table below, it reveals that $4.2 \%$ of the sample did not answer, $6.3 \%$ sa id it is because it is affordable, the comfort is given as a reason for patronage by $11.1 \%, 18.3 \%$ said the reason is it relia bility, a majority of the sample (51.8\%) said the reason is that it reduces waiting time while the remaining $8.3 \%$ sa id it's because there is no other a ltemative means of transportation.

Table 7. Rea sons for patronizing motorc ycle operators

\begin{tabular}{|ll|l|l|}
\hline & & Frequency & Percent \\
\hline Valid & No response & 8 & 4.2 \\
& Cheapness or a fforda bility & 12 & 6.3 \\
& Comfort & 21 & 11.1 \\
Relia bility & 35 & 18.3 \\
Reduced waiting time & 99 & 51.8 \\
No altema tive means & 16 & 8.3 \\
Total & 191 & 100.0 \\
\hline
\end{tabular}

Sourc e: Field work, 2016

The figure below shows that $56.8 \%$ of the users of motorcycle do not have a car of their own, though $35.5 \%$ sa id they have a car that is for their private use while the remaining $7.7 \%$ said their car is used for commercial purposes.

On asking the user of motorcycle if an operator has ever offered them helmet before, the responses shows that $14.7 \%$ of the sample have been offered helmet, $79.1 \%$ said they have never been offered and $3.1 \%$ of them are not sure, the rema ining $3.1 \%$ did not answer the question.

Table 8. Offer of helmet to User by motorc ycle operators

\begin{tabular}{|ll|l|l|}
\hline & & Frequency & Percent \\
\hline Valid & No response & 6 & 3.1 \\
& Yes & 28 & 14.7 \\
& No & 151 & 79.1 \\
Not sure & 6 & 3.1 \\
Total & 191 & 100.0 \\
\hline
\end{tabular}

Sourc e: Field work, 2016 




Figure 2. Commuters ownership of car

Source: Field work, 2016

In terms of the perception of the users of motorcycle on safety standards, it was observed that $8.7 \%$ rated the safety standards as high, $27.9 \%$ viewed the level of safety standards as moderate while the majority (being 63.4\%) rated the level of safety standards as poor. 


\section{Logistics \& Susta ina ble Tra nsp ort \\ Vol. 8, No. 1, May 2017, 62-71 \\ doi: 10.1515/jlst-2017-0006}

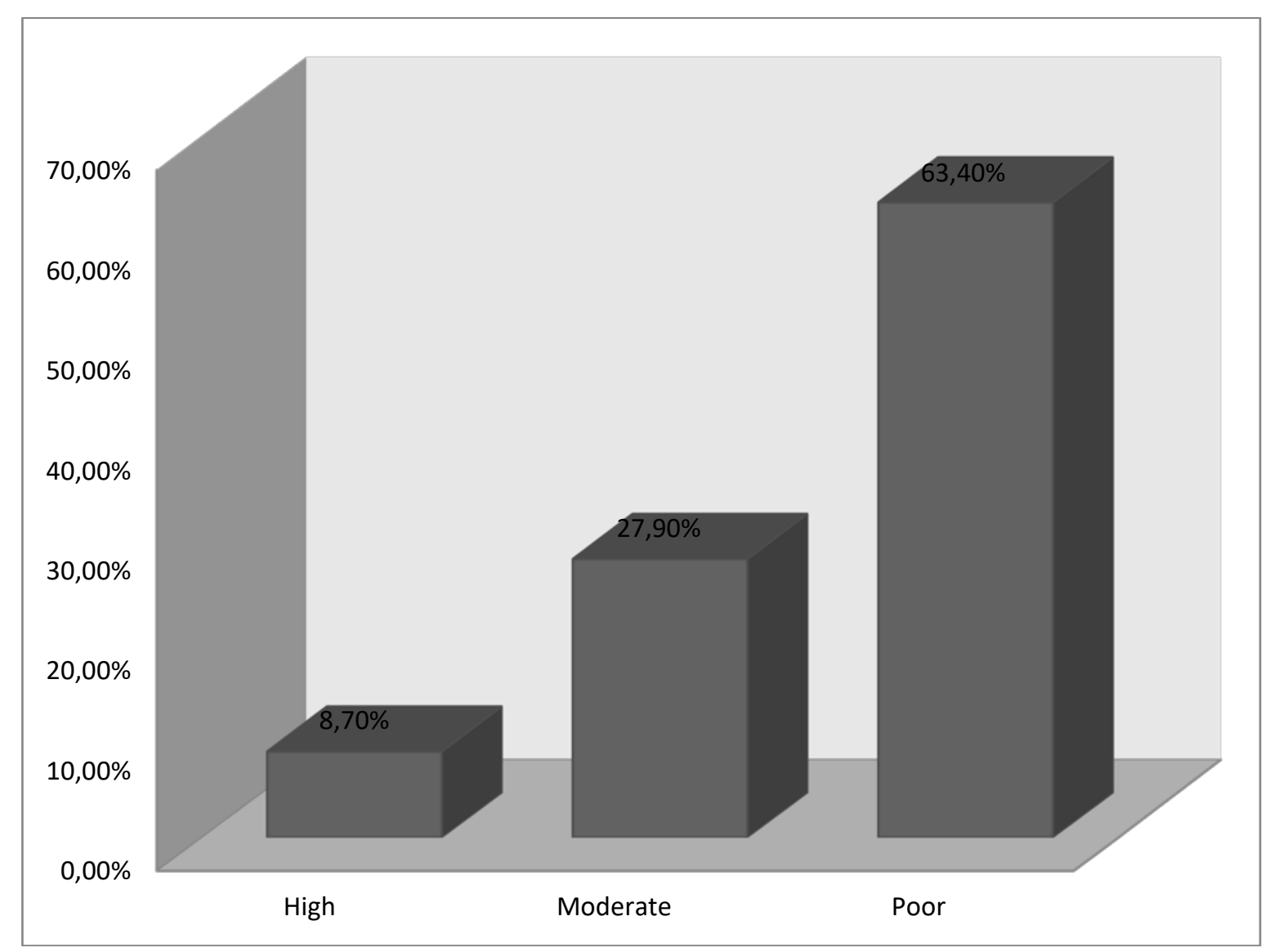

Figure 3. Users rating of safety standards by operators of motorcycle Sourc e: Field work, 2016

\section{RECOMENDATION}

In developing road transportation in Nigeria effort should be intensify by govemment to rehabilitate bad roads in Ogun State. In some areas where buses are completely absent, efforts should be made to encourage the use of tricycle which provides more protection than motorcycles. Improvements of the operational efficiencies of city taxi will go a long way in reducing road accidents and thus reducing the influx of commercial motorcycles. Regulation on compulsory use of safety gadget, such as protective head helmets, goggles, hand cloves etc., should be enforced, and also users (passengers) of commercial motorcycle should be sensitized and be educated on the benefit of the usage of protective head helmets. The Nigerian govemment should provide employment opportunities for our teeming youth as this will go a long way in the reduction of number of youth who as a result of unemployment took to motorcycle riding business. Invariably, national economic development policies should be designed in such that they can stimulate broad range of urban employment opportunities that are labour intensive coupled with the capacity to encourage effective utilization of natural and human resources. 


\section{AUTHORS}

A. Oluwaseyi J oseph AFOLAB is with the Bells University of Technology, Management Technology Department, College of Management Sciences, Ota, Ogun State, Nigeria. He is a lecturer in Logistics and Supply Chain Management and doctoral student with research interest in Transport safety and education, and Logistics and physical distribution management. (email: afolabiseyo@yahoo.com).

B. Dr. Kolawole Taofeek GBADAMOSI is with the Federal University of Technology, Transport Management Technology Department, College of Management Technology, Akure, Ondo State, Nigeria. He is a reader in Transport Planning and Management (email: kt_bad@yahoo.com)C.

Manuscript received by 4 November 2016.

\section{REFERENCES}

1. Adesanya, A. (1998). The use of motorcycle for public transport. NISER Monograph Series No. 6. 1998, NISER, Ibadan.

2. Adesanya, A. (2004). Analysis and Management of Transport Sector Performance and Its Intersectoral Linkages. A paper Presented at the Training Programme on Sectoral Polic y Analysis and Management, lbadan.

3. Badejo, B.A. (2002). The dilemma of emerging urban public transportation in Nigeria. Lasu J oumal of Social Sc ience Vol.4.

4. Badejo, B.A. (2007). Multi-modal Transportation System. The Future of Sustainable Transport: A paper presented at National Conference on Transport Development. Sheraton Hotels and Towers. Abuja.

5. Bassey, J.O. (2000). Public Transport in Uyo. The use of motorcycle mode: Unpublished M.Sc transport studies Dissertation, Centre for transport studies, Ogun State University, Ago-Iwoye, Nigeria .

6. Bawa-Allah, T.O. (1997). Lagos transportation overview. Public transportation in Nigeria: Editorial Production Consultant, Abeokuta Ogun State.

7. Gbadamosi, K.T. (2006). The Emergence of Motorcycle in Urban Transportation in Nigeria and its Implic ation on Traffic Safety. Centre for transport studies. Olabisi Onabanjo University, Ago-Iwoye.

8. Ogwude, I. (2011). Transport Infra struc ture and Mobility in Nigeria. J oumal of Environmental Studies.

9. Ogunsanya, A.A. and Galtima, M. (1993). Motorcycle in Public Passenger Transport Service in Nigeria: A case Study of Yola Town, in Ikya, S.G.(ed) Urban Passenger Transportation in Nigeria. Heinemann Educational Books (Nig) lbadan.

10. Oni, S.I. and Okanlawon, K.R. (2010). Transportation Education in Nigeria: in Exploring the Multifaceted Dimensions in Exercise and Sports Psychology, Ikulayo,P.(ed), Olu-Akin Publishers, Ibadan, pp.106-118.

11. Oni, S.I. and Olagunju, Y.K. (2010). The Motorcycle Crash Charateristics in Lagos State, Nigeria. J oumal of Environmental and Sa fety Vol 2, No. 1. pp 1-15.

12. Oyesiku, O. (2002). From womb to Tomb. 24th university ina ugural lecture: Ola bisi Ona banjo University Press, Ago Iwoye, Nigeria.

13. Oyesiku, O. (2002). Polic y Framework for urban motorc yc le public transport system in Nigenia Cities: In Xavier Godard and Innocent Fatonzon (eds) Urban mobility For All, Lisse: A.A. Balkema, pp. 255261.

14. Oyesiku, O. and Somuyiwa, B. (2010). Passengers' Satisfaction, Driver and Bus Sc heduling: The Ca se of Lagos Metropolis.

15. Sumaila, A.G (2004). Operation and Management of Public Transport. In Chikolo, I. Ogunsanya, A.A. and Suma ila, A.G. (Eds). Perspectives on Urban Transportation in Nigeria. NITT. Zaria. 